\title{
ELIAS CANETTI AND THE EMPTY GROUND FOR RIGHT
}

\author{
Corrado Punzi ${ }^{1}$ \\ Università del Salento, Italia
}

http://dx.doi.org/10.5209/rev_NOMA.2013.v39.n3.48330

\begin{abstract}
Trying to highlight the juridical reflection of a writer like Elias Canetti at the beginning could let puzzled both people who distrust the relationship between literature and law and people who consider Canetti's academic contribution is exiguous or confined to a psychosociological analysis of crowd and power. However, even if Canetti speaks actually seldom about right and let it tacit coincide with power, according to us it is possible to demonstrate as the concept of Law, even if in a twilight zone, permeate the entire Canetti's narration and constitute the key brick to support and interpret the whole architecture of his thought. In fact, Canetti's intense keenness on Kafka, allows him to inherit his vision of power and law, but even to elaborate on it
\end{abstract}

Keywords.- Law; power, metamorphosis

\section{Prologue}

Trying to highlight the juridical reflection of a writer like Elias Canetti at the beginning could let puzzled both people who distrust the relationship between literature and law and people who consider Canetti's academic contribution is exiguous or confined to a psycho- sociological analysis of crowd and power. However, even if Canetti speaks actually seldom about right and let it tacit coincide with power, according to us it is possible to demonstrate as the concept of Law, even if in a twilight zone, permeate the entire Canetti's narration and constitute the key brick to support and interpret the whole architecture of his thought. In fact, Canetti's intense keenness on Kafka, allows him to inherit his vision of power and law, but even to elaborate on it; the same could be said about another theme borrowed by Kafka: metamorphosis.

At this work we'll try to demonstrate, therefore, how central is the function of law by Canetti, that's to say its ability to stop the metamorphosis through territorialisation $^{2}$. In fact, according to us, when Canetti focuses on how men have structured their entire life on distances ${ }^{3}$, indirectly he wants to let understand the function of law is to detect and separate territories (legal or not), that's really to say, to produce distances. The same distances that, according to Canetti, are reproduced by people who pretend to guard a theme of communication starting by a specific academic territory. So, Canetti's interest in Law, borrowed by his passion on kafka, is an obsession coming from, and the

$1 \quad$ Corrado Punzi has a PhD in Law. He has conducted research in Chile, Brazil, Burundi and Spain, analyzing the processes of democratization in the suburbs of modernity. Currently conducts research at the Lecce's Centro di studi sul rischio founded by Raffaele De Giorgi and Niklas Luhmann. He wrote a book entitled Democracy as a paradox. Converging Paths: Luhmann, Foucault, Canetti, Think, Lecce, 2011

2 Rousseau claimed the ability of the law to the territorialisation: «when the state is instituted, residence give consent: to be resident into its territory means to abide by its authority" ». Cfr. (1955) KELSEN, Hans, I fondamenti della democrazia, in Id., La democrazia, (tr. 1995) II Mulino, Bologna, pp. 236-237

3 Cfr. (1960) CANETTI, Elias, Crowd and power, (Tr. Furio Jesi 2004) Adelphi, Milano, pp. 17-22 
same time coinciding, not only the repudiation of the same Law, but also the repudiation of any academic territorialisation.

For this reason, to understand the complexity of Canetti's thought it is necessary to overcame the prejudice of they who decry any kind of contamination between right and literature, but also of they who think Canetti focused only on the relationships between Crowd and power. According to us, in the involving size of the philosophical - juridical reflection of Canetti it is possible to find the effectiveness of his thought and in his way to be deterritorialized it is possible to understand his refusal of the function of territorialisation operated both by the law and the academy.

\section{A de- territorialized writer}

Elias Canetti is a stateless Jew, but not in the reductive sense he is a man without a town, but in the deepest sense he is a de- territorialized, that's to say a man who refuses any kind of identification, any kind of fixed territory, juridical, political or social. The one that more than the others territorializes is really the juridical: according to Brighenti, in fact:

Law is constitutionally territorial. Its territories are not necessarily spaces in the geographical sense, but relational forms between people and their corpses. A personal law makes the corpse a territory, a law that penalizes the crime of opinion makes the thought a territory. In a word, a territory develops every time we draw the line able to re- define relationships between subjects and functions in the reciprocal connections ${ }^{4}$.

In this perspective, it could be affirmed Canetti is a stateless belonging to any territory in the world, because the only laws he relays on are the quantum mechanic ones, that's to say the only laws that allow him to be a particle that is in the same time here and elsewhere, one and manifold. Canetti's life and literary work testify his nomadism lacking a territory, a will to refuse every country and every law, because, to him "the best definition of country is library". 5

Canetti is born in Bulgaria in 1905 and dies in Switzerland, to Zurich, in 1994, but spends his youth in Austria, to Vienna, 'till when, because of the Nazism, he is forced to move to London and to become a naturalized Britain. He gained a degree in chemistry, but never worked as a chemist and goes along with his passion for literature, till he won the Nobel prize in Literature in 1981. Yet, despite the Nobel prize, Canetti is an atypical writer, he wrote only a novel, Auto da fè, when it was 30 years old, in 1935, nearly 50 years before he won the Nobel. So, the Nobel in literature he won has been more a career recognition. During his career Canetti wrote dramas and comedies, aphorisms an three autobiographies. Nevertheless, the inheritance he left are not this works or his only novel Auto da fé. The work that allowed him to reach the world fame is an atypical essay, Crowds and Power. A book that, just like his author, could hardly

4 2009) BRIGHENTI, Andrea, Elias Canetti. Le voci del diritto, in G. Campesi, I. Pupolizio, N. Riva (a cura di), Diritto e teoria sociale. Introduzione al pensiero sociologico contemporaneo, Carocci, Roma

5 (1935) CANETTI, Elias, Auto da fé, (tr. Bianca e Luciano Zagari 1981) Adelphi, Milano,

p. 62 
be classified in a particular literary kind, but that still nowadays is recognized as one of the literary masterpiece in the '900s. It is hard to be classified because even in this only essays, that just to be an essay could be interesting for the academy, Canetti "doesn't employ neither the method nor the orthodox sociological language ${ }^{6 "}$. He suggests an "heterodox"7 reflection, close to anthropology, psychology, and even ethology. It is his multidisciplinary approach to make his classification and analysis difficult but this is what Canetti wants to avoid, because he refuses any kind of systematization of the thought ${ }^{8}$ and he doesn't want to submit to the academic idea claiming for the one and the other to be identical, that's to say specialization, as principle of greatness. "All his life, as he himself uses to say, is no more than a desperate effort to remove the division of labour" " that is locking a subject in a role, knowledge in a discipline: Canetti refuses systems and borders and this is why he leaks typical academic ways of representation ${ }^{10}$. His production so becomes heterogeneous in its forms, but continuing and obsessive in its contents. Indeed he himself affirmed he has written always the same work, he has always been obsessed by an only theme, clearly declared after in his more important anti- scientific treatise: Crowds and power, precisely. Crowds concept is fundamental because it allows to enter Canetti's rooms of power and right, rooms almost always coinciding and lived by the same elements: judgement, command, sentence. Therefore rooms where it is possible to see portraits very similar to those painted by Kafka. As in Kafka's, in fact, also in Crowds and power emerges an extensive and juridical - coercive vision of the power. So it is possible to highlight Canetti's juridical reflexion only after having mentioned his vision of the power.

\section{Crowds and power: life and death}

Canetti begins to write Crowds and power when he was 20 years old, in 1925 and ends it 35 years later, in 1960. His purpose is to try to grab the century by its throat ${ }^{11}$ : those same Nineties that disseminates death trough its totalitarianisms and forces Canetti, as Hebrew, to leave Vienna and to take

(2006) BRIGHENTI, Andrea, Per una sociologia del comando. Riflessioni su un tema di Elias Canetti, in "Sociologia del diritto" n. 1, p. 20

$7 \quad$ Ivi, p. 21

$8 \quad$ In one of his correspondences with the Italian sociologist Enzo Rutigliano, Canetti clarifies his refusal of any kind of systematization of the thought: "there is a good reason because I don't want to enter into details about the critics and about Crowd and power: what I want was to give an impulse to the discussion and not to set a system. If ever I would have made every effort to do the contrary: to avoid that my thought acquired the nature of a concluded unit" . Cfr. (2007) RUTIGLIANO, Enzo, Il linguaggio delle masse. Sulla sociologia di Elias Canetti, Dedalo, Bari, p. 88.

(1973) CANETTI, Elias, La provincia dell'uomo. Quaderni di appunti 1942-1960, (tr. Furio Jesi 1978) Adelphi, Milano, p. 55

10 Traditional academic culture leans or snubs Canetti because of methodological reasons. For example, Adorno, reports a methodological problem about Crowds and Power and expresses as follows: what in his work first strikes a thinker like me, no matter if he is called philosopher or sociologist, and, if I could say it openly, it is a little shameful, is what I should call the subjectivity of the approach [...] as subjectivity I mean rather leaking out from the subjects taken into consideration, so, to say it in a more pregnant, more extensive way, leaking out from the ways of representation" Cfr. RUTIGLIANO, Enzo, ivi, pp. 11-12

11 Canetti wrote this phrase in a note in 1959, the day after he send the hand written Mass and power to the publishing Claassen in Amburgo». (1986) GALLI, Matteo, Invito alla lettura di Elias Canetti, Mursia, Milano, p. 70 
refuge to London. To Canetti to tell the century is not simply to tell the violence of the totalitarianisms but to see, to their excess, those constants of the power that "are not suitable to be modified by the developing of social and economical structures." ${ }^{12}$ Canetti replaces history with the myth "as a Nietzche's place in which the equal always comes back." ${ }^{13}$ That is why he starts his analysis from a description of the crowds and of the power in the animal world and this is why he presents first of all an ethology of the power. He describes the animal world because he intends to unmask the individual and his presumed humanity, to deprive him of his rationality and to find analogies between man and animal. This way "he upsets at least two centuries of the European and occidental culture - aimed at increasing the individual, the individuality, his autonomy- in favour of what the West had always devalued as a regressive and irrational phenomenon: the crowd. ${ }^{14}$ So, he replaces the history with the myth, because he can't see in the history the improvement of a universal reason but a place of death, where the rituals of power use to play. So totalitarianisms are only one of the effects of that rough process of sectoralisation of the activities and obsessive specialization that modernity pursues. That process of bureaucratisation that encloses man in the Weberian steel cage, that's to say in a bureau and in a role, reducing him to a machine specialized in a task and confined in a production and, over all, a command line. That's the reason why, in his novel and in his plays, Canetti describes his characters as acoustic masks, because the mask is the sign of the stiffening of man, of an identity fixed in a role and in a task, and unable to change. That one produced by totalitarian regime, so, is only a more visible death, because even every modern democracy produces daily the death of the roaring ocean ${ }^{15}$ that lives in us, stares it in an aquarium, turns it slowly into a pond. From whatever perspective we watch the reality, "death is becoming the supreme law of the world"16.

Then, to try to grab the century to the throat, is to try to understand which are the constants of the power, how human life is forced by Power and Law. So the dualism between crowds and power expresses a deeper dualism, that one between life and death: on one side there is the crowds, that's to say multiplicity, metamorphosis, life, and, on the other side, the power, that's unity, identity, death $^{17}$.

So the crowd doesn't indicate neither a subject nor least at all an object, but it is a natural instinct shaking every single individual: the impulse to transformation, that's to say to metamorphosis. The crowd is on the other side of power and Law. From this simple consideration, we can understand how much canettian analysis of the crowd is far from all the other analysis, previous or

12 (2008) MUSOLINO, Enzo, Potere e paranoia. II concetto di potere nell'analisi di Elias Canetti, II Prato, Saonara, p. 66

(1986) GALLI, Matteo, ivi, p. 70

14 (2007) RUTIGLIANO, Enzo, ivi, p. 12

15 Canetti compares the effect of the crowd to that of a raring ocean "sometimes the crowd overflows onto us, a bellowing storm, a only roaming ocean in which every drop lives and wants the same thing of all the others. For the moment it still uses to dissolve again and so we are ourselves again, poor lonely devils". (1935) CANETTI, Elias, Auto da fé, (tr. Bianca e Luciano Zagari 1981) Adelphi, Milano, p. 469

$16 \quad$ (1986) GALLI, Matteo, ivi, p. 136

17 Cfr. (1990) ISHAGHPOUR, Youssef, Elias Canetti. Metamorfosi e identità, Bollati Boringhieri, Torino 2005 
contemporary: in fact sociology and psychology have leaned and lean commonly to interpret the crowd in a negative meaning, through perspectives able to underline irrational and uniform aspects: the homologation of the individuals, their regression to a pre- rational and emotional state. Canetti refuses these classical analysis and considers crowd as a natural instinct. According to him, it reigns over society what he defines the fear to be touched, the dread of the other. The crowd constitutes, first of all, the reversal of this dread. From these paragraphs we can immediately understand that according to Canetti, power and law produce distances, separate the crowd and create the individual and the individualism. Modern individual, and his dread to be touched and so his will to keep the distance, could only be the product of power and law. On the other side the fear is not the simple dread to be touched by the other, by the one who is different but is. at the same time, and in a deeper way, the fear to be touched by death. Paradoxically, however, the production of distance, is to Canetti, production of distance in life and, consequently, approach to death. The law that produces distances by right has a deadly power: the power to annihilate every kind of metamorphosis.

The fear to be touched highlights a primary need that, according to Canetti, characterizes men as animals: the need of survival. Survival, therefore constitutes the border between life and death and then it is also the unity of distinction, the dividing line that allows to understand the difference between crowd and power. Canetti employs the concept of survival, however, to indicate not only people who obey a power, but also people who hold it. He indicates, therefore, the two side of power and right. In fact the concept of survival explains not only paranoiac and destructive power that wants to survive to everybody, but also the intuitive and universal need of those who'll never experience the power, but only the hope to survive, to thicken the fence that separates life and death. On one side, therefore, the survival of those who fight to experience the power, to pass judgement on the others, to territorialize them and to stop their metamorphosis; on the other side the survival of those who daily fight to avoid their death, not to be tied into an identity. Every struggle is related to death, biological and spiritual. That's why in the matter of death Canetti argues: "I think it is useless and wicked as always, it seems to me the primeval evil of all what live, unsolved and incomprehensible, the knot in which all is hold and tight from time immemorial and nobody has dared to cut". ${ }^{18}$

The incomprehensibility and unavoidability of the death are also the incomprehensibility and unavoidability of the power. To Canetti, death is the same core of every slavery and it is why it is possible to interpret its description in right as the autopsy of the law: not because right is dead but because it is described - as we said- in its deadly function. Not to die, in fact, every individual turns himself into a "slave" and obey the deadly power of the law, because it, paradoxically, is able to assure him against death, to guarantee his survival.

This perspective leads Isabella Adinolfi to claim that Canetti joins Schopenhauer's thesis and the ones of his disciple, Nietsche. In fact, talking about survival, Canetti shows he shares Schopenauer's idea that man is moved by "an irrational will to live, the struggle for self - preservation, for his

18

(1973) CANETTI, Elias, La provincia dell'uomo. Quaderni di appunti 1942-1960, (tr. Furio Jesi 1978) Adelphi, Milano, p. 94 
existence" 19 like Nietzsche, on the other hand. Canetti believes that man aims "not only at the preservation of his life, but also at its development and increasing" 20 . An instinct called by Nietzsche will and power. Canetti, instead, talks about the instinct of improvement, to indicate not only paranoiac power, but also that need everyone has (men and animals) to be a big eater, to feel always plumper, a time the primary need of nourishing enough to survive is assured.

\section{An ethology of the power: from the repressive power to the productive one}

We told that Canetti begins his analysis - of the crowd before and then of the power - starting from the animal world. This choice is motivated not only by his will to show analogies between man and animal, but also by his will to mark out a way in which it is possible to follow the evolution of the power, that's to say its transformation from repressive to productive. Overall, Canetti claims power is "more ancient than language, otherwise dogs couldn't know it". ${ }^{21}$ Secondly, he states that the same concept of power has any connection with doing, but it is characterized by its ability to find obedience apart from doing, that's it doesn't need any action: to be effective it has only to be present. As a consequence, to him, the most ancient form of power is the escape command. For example, it is enough the motionless presence of a lion, its ability to reach quickly its prey, that this last get the pre - linguistic command to escape. So his approach is based on proxemics: it's another time the distance to be significant because it is just the distance between the bodies to send a concise and clear escape command. For this reason, Canettian analysis of the power has be defined as a sociology of the command ${ }^{22}$ : on the other side, the command, to Canetti, is still a sentence: it is anticipated by a judgement about the available forces on one field and the other and it is followed by a sentence, always a death one.

Death sentence allows us to outline the difference between force and power. When the command is still a death sentence we can talk about force and not about power. Force "is more urgent and immediate than power". ${ }^{23}$ Power is less extemporaneous and dynamic and, so, allows more space and time: in a single world, it allows to hope. To better clarify, Canetti describes the typical struggle between a cat and a mouse. After the cat seizes the mouse - Canetti writes - it let him run caper and let it escape the immediate area of its force: the mouse has the hope to survive, to get back to move free. Actually, even if the cat grants the mouse space and time to act autonomously, it continues to keeps tab on it, it continues to be interested in its destruction: " all this together, space, hope, surveillance, interest in destruction, could be defined the same body of power or, simply, the same power". ${ }^{24}$ When the cat decides to seize and incorporate the mouse, the power is shown, but as force: destruction is what turns power in force. Repressive power, therefore, reaches the peak of its negativity when it

\footnotetext{
19 (2008) ADINOLFI, Isabella, Prefazione, in MUSOLINO, Enzo, ivi, p. 5

$20 \quad$ Ibidem

21 (1960) CANETTI, Elias, Crowd and power, cit., pp. 367-368

22 Cfr. (2006) BRIGHENTI, Andrea, Per una sociologia del comando. Riflessioni su un tema di Elias Canetti, in "Sociologia del diritto" n. 1

(1960) CANETTI, Elias, Crowd and power, cit., pp. 339

$24 \quad$ Ivi, p. 340
} 
shows without any claim to find obedience, but only as a will to destroy the opponent, to eat him. It's not an accident if Canetti's analysis of the power starts from the description of the organs of power: claws and mouth whose function is to seize, eat and incorporate the prey. This functions are perfectly visible even in the human world, overall trough the example of the many sovereigns who identified with the lion, as the great seizer. Man replaced the claw of feline with the hand keeping the hold and, in fact, in every language we can commonly find expressions that claim hand as the symbol of power: it was delivered in his hand", "it lies in his hands", in the hand of God". ${ }^{25}$ However, hand seizes not only because it is interested in destruction: it is also able to be precise and patience, that's to say to model the environment even in a utilitarian and productive sense. The description of the different functions of the hand, its violence and patience, needs to Canetti to underline, symbolically and indirectly, repressive and productive features of modern power: "even in the advanced modern perfection, [.....]the technique shows as raised emanation of that games of violence and patience that our ancestor's hands exercised in the youth of humanity". ${ }^{26}$ So even the narrow space delimited by teeth becomes model of prison: to Mcluhan it is as if prison were an extension of teeth that has the possibility to stop and halt the prey, the body as an object of dominion. On the other side, teeth has been the symbol of the chamber of torture and of the savagery above the body until when, in modern age, their smoothness "won the world" 27 and so prisons "turned in a puritan sense" 28 and "our modern period costume requires eating is keeping the mouth shut". So that even the light menace unvoiced in the innocent opening of the mouth is shortened". ${ }^{29}$ It is clear, then, as Canetti, conceiving the organs of the body as symbols, is able to tell about the transformations of power and of penal institutes, and in particular, about their modern necessity to be felt as productive, concealing all the repressive aspects, the ferocity that continues to characterize them, to be a possibility. On the other side, by continuing his thought, Canetti notices that in spite we try eating in the most composed way as possible, we continue to eat using knife and the food cut into pieces and put in mouth "is called morsel even in modern languages". 30

In the symbolic analysis by Canetti, eating becomes metaphor of the exercise of the power. The person subjected to power is not only object of the power, but food for the powerful, prey seized and imprisoned in jaws, ingested and digested. The hand seizes, the teeth crush and break in small pieces, the stomach becomes more and more full.

But modern power doesn't limit to destroy, but eat because the food could become useful, providing energy and fullness: so modern power "don't let its subject to be slaughtered in shambles and doesn't change them into food for its body, it will deny to exploit them and digest. Rather it is it that feeds them." ${ }^{31}$. On the other side as man kills the animals when they are no more useful alive,

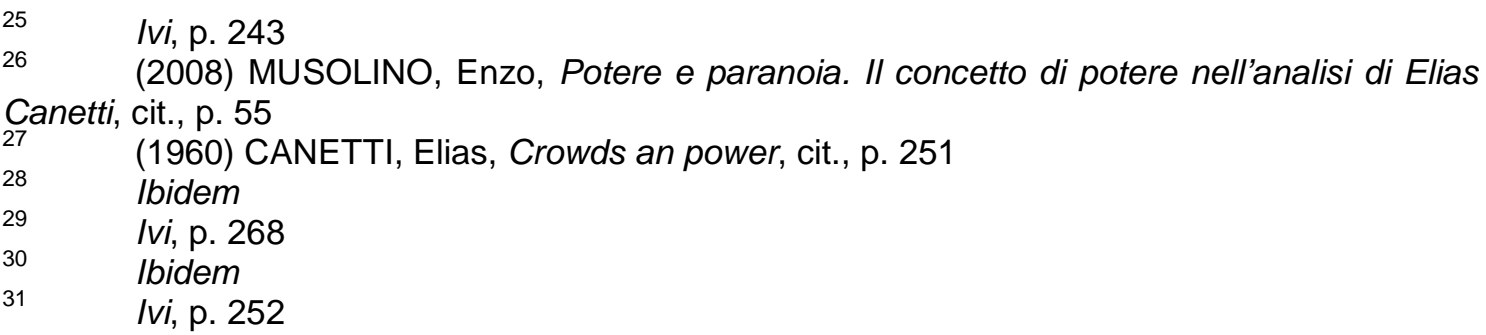


in the same way digestion and so the elimination of the human prey occurs only when the prey is no more exploitable: when it has been too much crashed and weakened by teeth or when it doesn't allow to be seized anymore, when it has been allowed time and space to move autonomously. Digestion and elimination entail prey's transformation in an excrement. Because of this, Canetti claims "the relationship every man has with his own excrements falls into the category of power. Nothing has belonged to a man more than what has became an excrement" ${ }^{32}$ We get rid of it in secret, because it is charged with the offence committed. By this vision, one of the two partners in the relationship not only owns the power, but owns even the other partner, considered an object. To us, therefore, by Canetti's perspective, we can consider the modern penal institutes could be interpreted as the functional equivalent to the organs of the body: their latent function is visible only after a comparison with the functions of power in the animal's world and in primitive societies. Latent function of right has to be kept concealed so as concealed is the moment in which food reappears as excrement. The power of right must remain power and never let be shown as force, as dominion and possession of a body, as surveillance of a space, as interest.

\section{Domestication of the command}

Through the concepts of nourishment and increase we can understand how Canetti examines more in details the productive aspects of power. If Canetti continued to describe symbolically only the relationships among animals, hardly he could cross the escape command, illustrate the productive power and explain why men obey the commands. To describe this, he analyses first the power man exercise over pets and, after, the power they exercise on one another, starting from its intensive form, the first we experiment: the power of a mother over her child.

Using only two phrases, Canetti is able to move his analysis from animal's world to the human one: " as we know it, command turned notably from its biological origin, that's to say the escape command. It is domesticated." ${ }^{33}$ To delve into this, Canetti describes the power that man exercises over animals.

The word domestication, in fact, indicates human ability to make an animal mild and to put it into a family environment. An animal respects commands trough the employment of training techniques, but therefore - and this is here the evolution- they are not based on physical constraint, inducing fear by violence: if an animal obeys the instructor's commands, it gains a reward, emotional or food. The domestication of the command occurs, then, when power turns from its biological violent origin and creates "a close relationship between nourishment guarantee and command." ${ }^{34}$ Obedience to power is closely linked to its ability to guarantee survival. The animal obeys the power of the master because this is a productive power, it make the life of the animal less difficult than the free life in nature. When productive power is able to guarantee not only the existence of the animal but even its well - being, we can consider that the relationship is no more between command and the guarantee of nourishment,

\begin{tabular}{ll}
\hline 32 & Ibidem \\
33 & (1960) CANETTI, Elias, Crowds and power, cit., p. 370 \\
34 & IVi, p. 371
\end{tabular}


but between command and the guarantee of increase. It is important to underline, therefore, to Canetti how the domestication of the command consists in a kind of corruption, because "the creature who lies in a state of subjection [...] is made accustomed to take nourishment only by a single hand." 35 This changes the relation of power into a relationship of property and the subject who lies in a state of subjection into an object of power. It's like this not only for animals but even for men, who since they are born experiment power starting from the mother's commands. This last, in fact, treats subconsciously the child as an object of power because he "collects, to the mother, the characteristics of plant and animal"36: as a plant, she cares about his growing; as an animal, he is kept prisoner and his movements are controlled. The power is no more destructive, because the mother doesn't eat her child, doesn't swallow him.

Mother is keen on feeding, and so she, in spite to turn her child into food for herself, guarantees food for him: " the concentration of lust for sovereignty over a so little creature provides the mother with a sense of predominance hard to be crossed in the course of the other normal relationship between men. There no other form of power more intensive than this" ${ }^{37}$ A mother can oppress the child with every kind of command, but the child runs always after her, as a dog rushes immediately when the master whistles. The child, as a domesticated animal, obeys the commands because power is guarantee for nourishment. In this sense, obedience is voluntary, but always caused by a state of subjection, by the fact that both dog and child have been corrupted by the power. That's why Canetti specifies that "the denaturation of the biological escape command educates men and animals in a sort of voluntary confinement." ${ }^{38}$

Some critic considers Canetti decreases social interaction to an Hobbesian "feeling of fear that someway keep every man prisoner" ${ }^{39}$ from paranoiac powerful to common people struggling for their own survival. In fact Canetti has a juridical - coercive view about power because he inherits his interest in the concept of fear from Hobbes. As Canetti himself admits, Hobbes "knows what fear is: his calculation reveals it. All they that came after [...] has only abstract from fear; so it has flown back again into obscurity, where it continues to act, undisturbed and nameless." 40 This shared interest in fear continues to draw Canetti's attention to Hobbes, even if he says "only few of his thoughts seem correct to me". ${ }^{41}$ In fact Canetti can't adopt totally Hobbes view because he, on the contrary of Hobbes, never describes the power in a vertex way, nor in an exclusively repressive way and, lastly, as a de - territorialized, he can't absolutely share the idea freedom could be obtained thanks to a great leviathan.

Canetti carries to the extremes the idea of fear so that it becomes fear of death. If on a side metamorphosis fascinates him, on the other it sets infinite insecurity.

\begin{tabular}{ll}
\hline 35 & Ibidem \\
36 & Ivi, p. 266 \\
37 & Ibidem \\
38 & Ivi, p. 371 \\
39 & Cfr. ADORNO, CANETTI, Dialogo, in U. Fadini (a cura di), Desiderio di vita. Adorno, \\
Canetti, Gehlen. Conversazioni sulle metamorfosi dell'umano, Mimesis, Milano 1995, pp. 61-82 \\
40 & (2006) ESPOSITO, Roberto, Possessioni, in AA.VV., Canetti, Cultura tedesca, n. 30, p. \\
93 & (2006) ESPOSITO, Roberto, Possessioni, in AA.VV., Canetti, Cultura tedesca, n. 30, p. \\
41 &
\end{tabular}


It doesn't provide orientations to the action and, overall, it could mean danger to die, because if metamorphosis isn't inside, we can't be able to live as deterritorialized, to face that complexity, to stay alive. Power and right, on the contrary, produce the subject and turn into a object making him identical to themselves, consistent, provided with tracks in which he can move. Power and right offer a static and structured life, but at least guarantee survival, biologic life and release from every fear of instability. And so the fear of death, the self preservation instinct, the shy and cautious nature lead to seek for protective shells, structures, voluntary confinements.

\section{Comedy of Vanity: the paradox of right}

To Canetti, as said before, modernity is paradoxically impregnated with death, because death is becoming the supreme law of the world. And the world, with its people and nations, self - defends stating his own being, as described in the ending of The comedy of vanity:

"Street. A dark stream crosses it. People flows in from every part. Everyone keeps a mirror or a portrait raised up. The air peals of furious cries. "I! I! I! I! I! I! I! I!. But all these voice aren't able to form a real choir" 42

Voices are not able to form a choir because the world doesn't defend by the crowd, it doesn't seek for metamorphosis, the increasing of its own complexity and contingency: it can't produce alternatives to identity. In this world it is possible only to watch our own mask, look our own fixity in the mirror.

Comedy of vanity, second play by Canetti, starts off with the emanation of an absurd and iconoclast law: the ban on using mirrors, photos and portraits, under penalty of prison or death. Beyond the ban of this law, so as every other law, there is an element characteristic of power and right as Canetti's thought: judgement. In this case, the judgment of "a dreadful spreading of vanity in all sectors of public and private life." 43

On the other hand, as the indefinite power this law releases, the devil hides in every mirror. So the manifest function of the command not to use mirror and pictures is to stop vanity, but its latent function is to stop metamorphosis: in fact if looking in a mirror is forbidden, even fixity can't be seen, nobody could never understand his own face is no more than an acoustic mask. If looking in a mirror is forbidden, the devil can't be met, he that crosses the line, he that seek for metamorphosis, he that as a writer is able to play every character, to embody everyone turning him into a possessed. That's so because power ask all mirror were destroyed and all pictures were burnt on a giant stake, and this can reminds the reader of the nazist stakes of books, happened only a few months before the Comedy was written ${ }^{44}$. The last act takes places in a "house of tolerance for image" ${ }^{45}$ where clients can contemplate in a mirror: on the strength

42 (1950) CANETTI, Elias, Comedy of vanity, (tr. Bianca Zagari 1982), in Id., Teatro, Einaudi, Torino, pp. 181-182

(1950) CANETTI, Elias, Comedy and vanity, (tr. Bianca Zagari 1982), in Id., Teatro, Einaudi, Torino, p. 90

$44 \quad$ Comedy of Vanity was written between 1933 and 1934, ma was published only in 1950.

45 1982) ZAGARI, Luciano, L'agorà falsificata, introduzione a CANETTI, Elias, Commedia della vanità, cit., p. XVII 
of prize they can choose three different cabins. But at the end, they realizes the house of tolerance has cheated them because there is no difference between the cabins e so they realize their blindness, the deceit operates both by the law and they who has institutionalized the way to breach it. So, angry, they rise against every form of institutionalization that is at the same time a way to stop metamorphosis and to create a distance. They so become that dark stream that flows in the street and raises mirrors and portraits while shouting "I! I! I! I!", without managing to be a choir. A dark stream that wants to have and not to be and continues to flow without never becoming crowd, at dawn of "new functions of image in the society of crowd." 46

This Canetti's Comedy is an allegory of right that, describing the absurdity of law, reminds of some pages by Kafka in the work On the law (1920) ${ }^{47}$ : "the only visible and undoubtable law imposed to us is nobility and we want to deprive of it?". The same way, to Canetti, the peculiarity of the command is "its indefinite and unquestionable character" 48 : "an order is an order"49. To Kafka law is undoubtable, to Canetti, unquestionable: its absurdity doesn't allow to assume a problem of acceptance. Obedience is due and can't be questioned because the effectiveness of right, so as that of power, consists in that peculiarity that Canetti defines as grasping. Like a lion seizes its prey with claws and stops it on the ground, at the same way power and right keep their hold on bodies and life of men and this way they territorialize them. To Canetti, "law is a right provided with power that, as such, seizes, swallows." ${ }^{50}$ Swallowing is to include, to steal the prey that ends up to be inside the predator, coinciding with him: this is why power and right produces the subject, his fear to be seized, swallowed and, to the limit, expelled secretly as excrement. On the other side, to judge entails a grasping, because to judge is like to bite: "between to live an experience and to judge there is the same difference that between to breath and to bite." 51 In fact, before to judge, question are asked with the aim of seizing he that has to answer because: "to ask a question means always acting to penetrate;" 52 but it means even, and another time, to territorialize.

\footnotetext{
"Always, even in everyday circumstances, the outcome of the answer is to stop someway he that has provided it [...]. The answer compels he that has provided it to stop in a given place, while the questioner can aim at him from everywhere; it is as the questioner could move around the questioned and frisk his place as required. [...] The questioner sets upon the questioned by asking and if he manages in touching him, that's to compel him to answer, he stops and sets him in a place. "who are you?". "I am Mr somebody". So the questioned can be nobody else no more or his lie will give him troubles. And so the possibility to

46 (1990) ISHAGHPOUR, Youssef, Elias Canetti. Metamorfosi e identità, (tr. 2005), cit., p. 106

$47 \quad$ This analogy between Kafka's work and the Canetti's Comedy is proposed by Brighenti. Cfr. (2006) BRIGHENTI, Andrea, cit., p. 314

49 (1960) CANETTI, Elias, Crowd and power , cit., p. 365

$49 \quad$ Ibidem

50 (2006) BRIGHENTI, Andrea, cit., p. 314

51 1990) CANETTI, Elias, La provincia dell'uomo. Quaderni di appunti 1942-2972, in Id., Opere, Vol.I, Bompiani, Milano, p. 1643

(1960) CANETTI, Elias, Crowds and power, cit., p. 344
} 
escape through metamorphosis has been stolen. This process, when continues for a certain time, can be considered a kind of chaining"

To judge is not a duty of the law because rights reproduces some duties present in every social area. In fact, as Canetti writes, "to pass judgement - illness is one of the most spread among men" 54 because it causes pleasure: "the one relegated in a group of inferior people and this let presume that someone better is used to pass judgement. We can heighten debasing the others." ${ }^{55}$ To Canetti, as to Kafka, right heightens so much that its judgement is still a sentence: a sentence to death, real or symbolic. In fact, if the efficiency of right depends on his ability to seize, this means that obedience to right and power could be obtained thanks to their close link to the dread to die and not because they have a ground.

That's why, in Their days are numbered, Canetti questions about the foundation of right by imaging a paradoxical society that is lacking anguish over death because every person knows how much he will live but he is not allowed to say. Everyone guards his own birth and death date in a capsule, sealed and hung on neck, and they call one another by the number of years they will live. Everyone, then, knows the date of his own death, but not the date of the others. Only the capsulain of the State, he that "has been settled as a guardian" ${ }^{26}$ is allowed to open the capsules when someone dies and to verify he is really dead in his Augenblick, when it was his time. In this paradoxical society murders don't exist and killers are named they who open or get stolen their own capsules or the ones of the others. "he that does it has to be set outside society. He wants to live without the capsule so he is a killer" ${ }^{27}$. As the capsulain says: "stability and safety of our society are based on the fact that everyone observes his time. I call it the contract. Everyone, when he's born, has his contract hung on the his neck" ${ }^{158}$ They whose name is a higher number form a powerful class, but everyone observes silently the social contract and, as an exchange, their fear is erased: because if the capsulain "allows someone to call into question his law, all would begin to wobble and the consequences would become countless. Everyone should assault each other and we would fall once again in the ancient shambles." ${ }^{59}$ Neverthless, a citizen, Fifty, believes that the capsulian could be a liar and tells to a friend, who claims that capsulain can't lie because "he has sworn in front of the state!" and "his only duty is to read truthful the contents of the capsule and let everybody knows $\mathrm{it}^{\mathrm{\prime}}{ }^{\circ 0}$. But Fifty believes that the capsulain "could have committed himself to lie by swearing" ${ }^{61}$ and so he introduces himself in front of the capsulain. He provokes him by telling his fiftieth year has arrived and, so, he pretends, his time has come: "FIFTY: do you tremble about your law? If this law is true, put it on the test. CAPSULAIN: Law can't be tested.

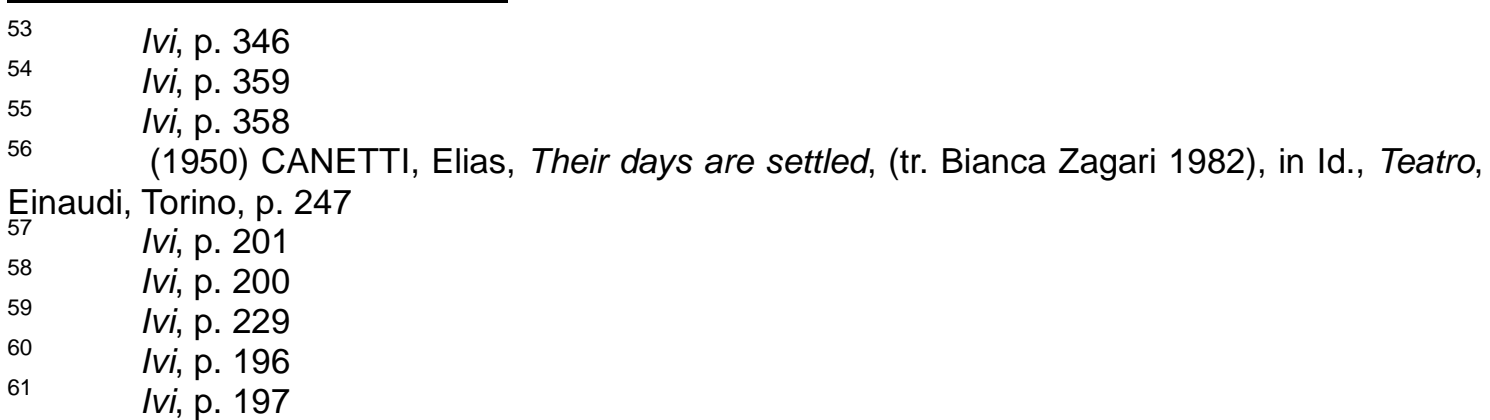


It is sacred."62 Law is sacred and never can go wrong. "CAPSULAIN: the contract is always exact. I can be mistaken. I perform an high and eminent charge. But I am not a god. I can be mistaken. But the contact never can go wrong" ${ }^{63}$. Fifty, then, questions law "is based on ignorance. CAPSULAIN: different laws don't exist. When we are talking about laws, the only important thing is they are complied. FIFTY: everybody has to comply with them?. CAPSULIAN: everybody who lives in the sphere of their effectiveness has to comply with them." ${ }^{64}$ The legitimacy of the law grounds, then, on its ability to territorialize: to seize they who live in its sphere of effectiveness and, from their birth, have the burden of a contract hung on their neck, a sacred burden, that's to say sacer, separated and secret. The same guardian of the law, even performing an high and noble charge, doesn't know what he has to guard: "his evaluations are doubtful. He is doubtful too. He defends something doubtful" 65 Here is the paradox: right provides certitudes, but it is based on doubtfulness. To put into doubt its ground would mean, nevertheless, to go back to an hobbesian feeling of fear and to fall again in the ancient shambles and all would assault each other.

As Matteo Galli explaines, citizens in this play are "spurred on a - Kafkian reverent fear of the law, of a power becoming dark executor of smoky disposals" ${ }^{\prime 6}$. But on the contrary of Kafka, Canetti concludes his play entrusting Fifty the task to be, definitively, a deterritorialized and to challenge the guardian of the law's door and, this way, entering the castle. So in the end Fifty steals the capsules of two passing people: they are empty. Then he opens his own capsule: even this is empty. Fifty now has become a killer, but he runs out in the street to announce publicly the end of the capsule age:

FIFTY: I don't care about you. I am indifferent to you. I am indifferent to you because you don't exist. You are not alive. You are all dead. I am the only one. I am alive. I don't when I'll die, that's why I am the only one. You crawl bearing that precious burden on neck.

[...] You are not even shadows. You are nothing. I walk among you only because I want you to know how much I despises you. Hear me, people, you good dead, even the years hung on your neck are false [...]. All is fake. The capsules hung on your neck are empty.

[....] There is nothing sure! Capsules are empty! All is doubtful and has always been." 67

I walk among you only because I want you to know how much I despises you. Canetti, just like Fifty, walks in territory he doesn't own, in a territory refused by him because he feels a deterritorialized, because he doesn't want a name having a sense and indicating a termination. He prefers to face the fear, to take the task to become a living metamorphosis through writing: in writing, he says

\footnotetext{
$62 \quad$ Ivi, p. 222

Ivi, p. 203

Ivi, p. 240

Ivi, p. 231

GALLI, Matteo, Invito alla lettura di Elias Canetti, cit., p. 63

(1950) CANETTI, Elias, The days are settled, (tr. Bianca Zagari 1982), in Id., Teatro,

Einaudi, Torino, p. 242
} 
the others how much he despises the so called humanity, but allows them to look inside the capsules, inside the paradoxes of power and right.

Capsules are empty: what's then the right of political power to exercise power? No one: its right grounds on an empty foundation, fictional. To say that capsules are empty is the same to say that the foundation governing all social functions is empty. So the right is paradoxical because its foundation is to have no ground. If this paradox isn't concealed, there is nothing sure, all is doubtful: right looses its function to stabilize the expectation of behaviour, to minimize complexity and to erase the fear of death. The right stops to produce security. So, free from the fear to open the capsule, men "have to feel again fear, anguish of death and of the uncertainty of their condition, that uncertainty they had been delivered from by the device of an oppressive law. How much are really able to live as deterritorialized? ${ }^{68,}$

\section{Epilogue}

In our opinion, Canetti's be obsessed with Kafka's theme of Law and metamorphosis, leads him to make this same thought the unity of the distinction between law and metamorphosis. So, even his most famous work, Crowds and power, can be read as a re - description of this unity. This means, Crowds and power isn't the analysis of two social objects particularly holding the interest of sociology and psychology of the first nineties: crowds isn't only a social object or a political subject, but it becomes a philosophical concept indicating only a part of that distinction Canetti cares about: metamorphosis. The other side, the law, is indicated by power. The distinction between crowds and power so becomes - as said before - the symbol of a wide and general one that embodies others more: the distinction between life and death. Metamorphosis has the vital function to allow escaping from the deadly function of law and power. In consequence, if Canetti's thought is the unity of distinction between metamorphosis and law, it can be described as the thought of survival, because survival is in turn the unity of distinction between life and death. The entire work by Canetti is an attempt to describe the coexistence of life and death: the fear of death is the core of every slavery and we can escape that spiritual death that the law leads us only by using metamorphosis. On this basis we can support, first, that the unavoidability of biological death can be won only by adapting the Canettian idea of metamorphosis to a desperate and maybe religious illusion, that's to say to a self- conviction that biological death is only another kind of metamorphosis. Secondly and as consequence, it is possible to support that Canetti cares not so much about biological death, but instead about spiritual and social death added up by power and the device of the law.

In conclusion, despite Canetti describes even political upsetting crowds, he is sure it is almost impossible to escape the power of territorialisation of the law. Nevertheless he continues to be troubled over the search for a possible solution, a way of escape from death, because he thinks that

"The most shaming thing in life is that at the end we accept all we has hated with pride and strength. So we arrive transformed to the point we left when we were young, in the same environment once we lived. But then where are we 
really? We are in the hard clearness trough which we can see and record all this." 69

Then Canetti rescues thanks to his passion for writing: to him the writer is "the guardian of metamorphosis and his writing is "the unbroken exercise of metamorphosis"70. Every character lives inside him and so represents his "resistance to death"71.

Canetti delivers from the deadly destiny becoming a modern Ulysses, able to be a beggar, so as to be Nobody: renouncing his own identity is not to turn into nothing, auto- denying, but so he can be, as in the work by Pirandello, One, none and one hundred thousands, that's to say continuous metamorphosis ${ }^{72}$. Writing rescues Canetti but he knows well that is a solitary rescue, philosophical not political. Anyway, indirectly, he indicates even to his readers a way of escape, consisting in not complying, abandoning to one's own passions, so becoming a living metamorphosis: they that don't comply are the salt of the earth, the colour of life, they sentence themselves to unhappiness, but they are our happiness. ${ }^{73 "}$

(2006) ESPOSITO, Roberto, Possessioni, in AA.VV., Canetti, Cultura tedesca, n. 30,

p. 96

(1976) CANETTI, Elias, La coscienza delle parole, (tr. Furio Jesi 1984), Adelphi, Milano, p. 388

71 Ibidem

72 In his speech hold in Munich in 1976 and called The mission of the writer, Canetti explains that in The Odyssey is told one of the most interesting form of resistance to death, of rebellion to nature and gods. In fact in The Odyssey, says Canetti "are told essentially the adventurous metamorphosis of a man called Odysseus. They are on their top when he comes back home into the shoes of a beggar., the most miserable man one can imagine. The simulation here is so perfect that any later writer has equalled it and least of all exceeded. Anyway Rutigliano says he looks from a perspective a little bit different than Canetti's one: we are sure that Odysseus metamorphosis allows him to deliver from Destiny and from the form as much insuperable it adopts. [...] Odysseus pay excessively this rescue. The price is his identity.[...] in this sense the top of the metamorphosis isn't his homecoming in the shoes of a beggar, as Canetti claims, but his transformation in Nobody during his adventure with Cyclops. The self- annihilation, the self- negation for rescue.[...]. It's a metamorphosis consuming the same substance and, at the end, it is possible to assimilate it to losing metamorphosis". Here, on the contrary, as can be read before, it is sustained an interpretation in opposition to that one of Rutigliano: it is claimed, in fact, Odysseus transformation into Nobody isn't a losing metamorphosis, and, on the other hand, it is hard to believe Canetti could ever associated the concept of metamorphosis to that of defeat.

73 (2003) CANETTI, Elias, Un regno di matite. Appunti 1992-1993, Adelphi, Milano, p. 18 